\title{
Energija, pravda i mir s motrišta socijalnog nauka Crkve
}

\author{
Krešimir Cerovac*
}

\begin{abstract}
Sažetak
Razvoj ljudske civilizacije usko je povezan s korištenjem energije i njezinih mnogostrukih izvora. Od doba ranih hominida na planetu, prije sedam milijuna godina, pa do sadašnjeg homo sapiens sapiens, energija je bila osnovni čimbenik opstanka vrste. Crkva općenito, a posebice kroz svoj socijalni nauk pokazuje posebno zanimanje za pitanja cjelovitog ljudskog razvoja, pa je tako predmet njezina razmatranja i pitanje energije, kao iznimnog izazova za pravdu, sigurnost $i$ mir u svijetu. S pitanjem globalne energetike bave se izravno pape Ivan Pavao II., Benedikt XVI. i Franjo, svjesni da ono spada u iznimno bitne znakove vremena, koje treba pretpostavljati, čitati i tumačiti u svjetlu evanđeoske mudrosti. Ipak, problematika energije, odnosno energetskog sustava, još uvijek je jedno zanemareno globalno pitanje današnjice, iako je iznimno bitan čimbenik za cjelovit razvoj i ljudsko dostojanstvo.

Ključne riječi: energetika, energetska politika, energetska pravda, energija, opće dobro, obnovljivi izvori energije, Papinski savjet za pravdu i mir, potrošnja, pravda, mir, sigurnost opskrbe, socijalni nauk Crkve
\end{abstract}

\section{Uvod}

Razvoj ljudske civilizacije usko je povezan s uporabom energije i njezinih mnogostrukih izvora. Od doba ranih hominida na planetu, prije sedam milijuna godina, pa do sadašnjeg homo sapiens sapiens, energija je bila temeljni čimbenik opstanka ljudske vrste. Ona je iznimno važan čimbenik u gospodarstvu, jer je nuždan uvjet za gospodarski rast svake zemlje. Sigurnost opskrbe energenata te njihova cijena imaju, s jedne strane, iznimno velik utjecaj na konkurentnost određenog gospodarstva, a s druge strane, značajno utječu na kvalitetu i troškove života. Stoga je pravilan pristup energetskoj problematici preduvjet za gospodarsku stabilnost. No, pojavljuju se, globalno uzevši, neka zabrinjavajuća pitanja u vezi s budućnošću energetskih sustava. Ponajprije, to je činjenica da porastom

* Mr. sc. Krešimir Cerovac, dipl. inž. el. Adresa: Našička 2, 10000 Zagreb, Hrvatska. E-pošta: kresimir.cerovac@xnet.hr 
broja stanovnika na Zemlji i rastućim napretkom u mnogim zemljama snažno buja energetska potrošnja koja, uz prijeporno pitanje sigurnosti opskrbe, ima izravno i snažan, negativan, utjecaj na okoliš. U skoroj se budućnosti očekuju poremećaji i poteškoće u opskrbi energijom, čak ako čovječanstvo i prijeđe na filozofiju umjerenog (održivog) gospodarskog rasta. Konačno, i dalje će, čini se, zbog nemogućnosti dogovora među vodećim zemljama svijeta, rasti opterećenje na okoliš koje izaziva energetski sektor, ponajprije zbog otpuštanja u atmosferu raznih plinova, a posebice ugljičnog dioksida.

Crkva općenito kroz svoj socijalni nauk pokazuje posebno zanimanje za pitanja cjelovitog ljudskog razvoja, pa je tako predmet njezina razmatranja i pitanje energije kao iznimnog izazova za pravdu, sigurnost i mir u svijetu. Energetska problematika, s kojim se izravno često bave pape Ivan Pavao II., Benedikt XVI. i Franjo, spada u iznimno bitne znakove vremena, koje treba čitati i tumačiti u svjetlu evanđeoske mudrosti.

S tim u vezi papa Ivan Pavao II. naglašavao je da Katoličkoj crkvi, po naravi njezine etičko-religijske nadležnosti,

pripada, da kaže svoju riječ pred određenim ljudskim prilikama, individualnim i zajedničkim, nacionalnim i internacionalnim, za koje formulira istinski nauk, tj. korpus koji joj dopušta da analizira društvenu stvarnost, da izreče o njoj svoje mišljenje i da naznači smjer za pravilno rješenje pitanja koja iz nje proistječu (CA 5).

Energija ${ }^{1}$ je, kako se često kaže, krvotok suvremenih društava, i stoga je treba prije svega, promatrati kao zajedničko dobro zajamčeno svima ljudima na Zemlji, a neprijeporno je da je strateški čimbenik označen dimenzijom mogućih ratnih sukoba. Da bi se izbjegle mnoge opasne pojave u svijetu, a vidljivo je da su neke već prisutne (ratovi i terorizam), »nužna je i svjetska preraspodjela energetskih izvora kako bi im se i one zemlje koje su ih lišene, mogle približiti« (CV 49). A o sudbini tih energetskih izvora »ne smije odlučivati ni pravo prvoga ni pravo jačega« (CV 49). S tim u vezi papa Ivan Pavao II. u enciklici Centesimus annus navodi: »Čini se, dakle, da je najveći problem steći pravedan prilaz međunarodnom tržištu koje se ne temelji na jednostranom načelu iskorištavanja prirodnih resursa, nego više na valorizaciji ljudskih sposobnosti« (CA 33).

»Nedostatan i nejednak pristup energiji treba smatrati preprekom cjelovitomu razvoju naroda i pravednomu društvu« (Energy, Justice and Peace, 2014, 33), upozorava Papinski savjet za pravdu i mir, te dodaje da je pitanje energije »izazov za pravdu i mir « (Energy, Justice and Peace, 2014, 11). Nepošteno, ili nepravedno, upravljanje energijom može ugroziti svjetski mir, te »cijeli ekosustav,

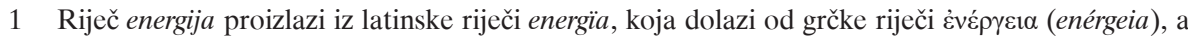
sastoji se od naglašavajućeg dijela en i ergon, izvršeni rad. Termin, koji se proteže i na neka druga shvaćanja, skovao je Aristotel, posebice da naznači stvarnu silu koja omogućava kretanje i djelovanje (Aristotel, 2001, 237; IX. 30. 1047b). »Energija (grč.). 1. Djelotvorna sila, životna aktivnost, odlučnost, odrješitost. 2. fiz sposobnost nekoga sustava da obavlja rad; oblici e.: mehanička, toplinska, električna, kemijska, nuklearna i dr. Oblici mehaničke e. su potencijalna i kinetička e. U zatvorenom sustavu e. je stalna; može joj se mijenjati samo oblik«(Anon., s. a.). Izvori energije mogu biti primarni (postoje u prirodi, poput ugljena, nafte, plina, vode, sunca, vjetra itd.) i sekundarni (dobiveni transformacijom, poput benzina ili električne energije). 
a time i opstanak čovječanstva« (AM 80), ukazuje papa Benedikt XVI. u postsinodalnoj apostolskoj pobudnici Africae munus, u kojoj govori o Crkvi u Africi kao čimbeniku u službi pomirenja, pravde i mira. A slično govori i papa Franjo ukazujući na to da »neravnomjerna raspodjela i korištenje energije«, među ostalim čimbenicima, spadaju u »društvene dimenzije globalnih promjena« (LS 46).

»Energija je, u svojim mnogim oblicima, Božji dar cijelomu čovječanstvu, pa stoga nije opravdano njezino nagomilavanje ili isključivo korištenje samo od nekolicine. Ona je, kao plod Stvaranja, oruđe povjereno čovječanstvu za zajednički rast na temelju solidarnosti« (Energy, Justice and Peace, 2014, 11-12), navodi se u izvješću Papinskog savjeta za pravdu i mir.

Treba imati na umu da stvoreno ima svoju vlastitu izvrsnost i osebujno savršenstvo, ali ono u potpunosti ne nastaje iz ruku Stvoritelja. »Stvoreno je«, kako kaže Katekizam katoličke crkve, »kao nešto 'na putu' prema nekom končanom savršenstvu za koje ga je Bog odredio i koje još treba dostići« (KKC 302). U tom bi smislu ljudska djelatnost i u slučaju razmatranja energetske problematike trebala biti potaknuta »eshatološkom sviješću i vođena nizom teleoloških razmišljanja, koja se protežu daleko izvan puke tehničke i instrumentalne racionalnosti « (Energy, Justice and Peace, 2014, 13).

Pitanje energije je iznimno velik izazov u današnjem vremenu miru, ponajprije jer u svijetu postoji uočljivo nejednaka rasprostranjenost tzv. neobnovljivih (fosilnih) izvora energije (prirodni plin, nafta, ugljen i uran) s jedne strane, te neujednačena potrošnja energije na nacionalnim razinama s druge strane. Međutim mnoge su države, iako nemaju značajnijih vlastitih energetskih izvora, stekle ipak povlašteni položaj u korištenju energenata zahvaljujući svojemu političkomu utjecaju, te snažnomu tehnološkomu i ekonomskomu razvitku. Dodatno stanje narušava i energetska siromašnost u mnogim zemljama u razvoju, jer nedostatak energije može predstavljati crtu razdiobe između života i smrti. ${ }^{2}$ Neravnotežu dodatno pogoršava i nejednakost, odnosno nemogućnost u pristupu novim tehnologijama vezanim uz energetiku. Sve to podsjeća na riječi pape Pija XI., koji je kazao da ne može biti prihvatljiva »silna i tako nepravedna razlika u raspodjeli vremenitih dobara «, odnosno da se ona »ne podudara s naumom premudrog Stvoritelja«(QA 5). Slično razmišlja i papa Ivan Pavao II. u svojoj prvoj enciklici Redemptor hominis:

Dobro je poznata slika potrošačke civilizacije, koja je označena određenim izobiljem dobara koja su potrebna čovjeku i cijelim zajednicama - a to se odnosi upravo na bogate i vrlo razvijene zajednice — dok preostale ljudske zajednice, barem njihova široka područja, gladuju i mnoge osobe svakodnevno umiru od gladi i neishranjenosti (RH 16).

Uz sve rečeno treba uzeti u obzir da pitanje energije uključuje još i energetske sustave, koji su i sociološko-tehnološke naravi, i koji ne uključuju samo strojeve, cjevovode, prijenosne mreže, rudnike, rafinerije i razne uređaje, nego i ljude,

2 Jedna četvrtina čovječanstva živi u nastambama bez pouzdanog i dostupnog pristupa grijanju, osvjetljavanju i kuhanju, a danas više ljudi, kao nikad ranije u povijesti, živi bez električne energije (Sovacool, 2013, 1). 
koji, osim što koriste i konzumiraju energiju, oblikuju i proizvode tehnologije, razvijaju i rukovode odgovarajućim postupcima. Usto, energetski sustavi uključuju i financijske mreže, radnu snagu i škole potrebne za osposobljavanje stručnjaka, ustanove za trgovanje energijom, ceste, raznovrsna regulatorna tijela, pravila o korištenju zemljišta, gradske četvrti i tvrtke, kao i društvene norme i vrijednosti koje osiguravaju njihovo pravilno funkcioniranje.

\section{Energija, kao složeni, potencijalno konfliktni čimbenik}

U posljednjih nekoliko godina javljaju se mnoge političke i gospodarske krize potaknute energetskim pitanjima, ili problemima vezanim na neki način uz energetsku politiku, posebice u području vađenja neobnovljivih energenata ili njihova tranzita. Pred više od 20 godina papa Ivan Pavao II. je na samom početku u poruci za Svjetski dan mira (1990.) napisao:

U naše doba raste svijest da svjetski mir nije ugrožen samo zbog utrke u naoružanju, regionalnih sukoba i trajne nepravde među ljudima i narodima, nego i zbog nedostatka dužnog poštovanja prema prirodi, pljačkanja prirodnih resursa i napredujućeg opadanja kvalitete života (Ivan Pavao II., 1990).

Iako, dakle, postoji sve veća svijest o navedenim pitanjima, stanje se ipak nije mnogo promijenilo. Dapače, utrka za gomilanjem, odnosno, kako kaže papa Benedikt XVI., »kaparenje neobnovljivih izvora, koje je postalo praksa nekih država, poduzeća i skupina moći« (CV 49) i dalje se odvija, te povremeno dovodi do ozbiljnih sukoba, koji se »često vode upravo na tlu spomenutih zemalja (misli se na zemlje bogate energetskim izvorima) i sa sobom nose poraznu bilancu smrti, uništenja i daljnjeg propadanja« (CV 49). Papinski savjet za pravdu i mir u svojem izvješću upozorava:

Uzimajući u obzir sadašnje kretanje na području energetike, sve se više izlažemo opasnosti da budemo uhvaćeni u nestabilnu situaciju s različitim rasadištima sukoba zbog nadzora nad energijom. Tu je situaciju sve teže nadzirati i može dovesti do strašnih posljedica (Energy, Justice and Peace, 2014, 81).

Zanimljivo je da je o toj problematici još pred više od 25 godina razmišljao i ugledni hrvatski katolički teolog Vjekoslav Bajsić (1924.-1994.). Među znakove trećeg tisućljeća ubrojio je, među ostalim, i problem energije, njezine potrošnje, te stanje njezinih izvora u budućnosti. Upozoravao je da bi zbog toga moglo doći do napetosti i nestabilnosti u svijetu. U Dubrovniku je, primjerice, na jednom skupu 1990. godine održao predavanje pod naslovom Duhovni pogledi na strateške energetske izazove. Iako Bajsić konstatira da su tržišno usmjerena društva materijalno i kulturno najrazvijenija, te s jakim osjećajem slobode, ipak upozorava:

Tržišno organizirano društvo nije štedljivo društvo. Njegova individualistička struktura, dominirajuće vrednovanje profita te zakon ponude i potražnje, prodavanje i kupovanje svega što može biti prodano ili kupljeno, sigurno nije u korist očuvanja energetskih izvora za budućnost (Bajsić, 1991).

Danas se sve više pokazuje da je Bajsićevo razmišljanje bilo itekako opravdano. 


\section{Energija, izazov modernog doba, izazov za pravdu i mir}

Neprijeporno je da je potreban novi obrazac u vezi s proizvodnjom, potrošnjom i distribucijom energije, koji bi trebao pružiti svima nove oblike ponašanja temeljenog na pravdi, odgovornosti, altruizmu, subsidijarnosti, te na koncepciji cjelovitog razvitka naroda s pogledom na zajedničko dobro, a sve u duhu socijalnog nauka crkve: Energiju treba promatrati kao svjetsko zajedničko dobro sa sveopćom namjenom.

Prvo vrelo svega što je dobro jest sam Božji čin kojim je stvorio zemlju i čovjeka te čovjeku predao zemlju da njome vlada svojim radom i uživa njegove plodove. Bog je dao zemlju svemu ljudskomu rodu da bi uzdržavala sve njegove članove ne isključujući ni privilegirajući nikoga. Tu je korijen opće namjene zemaljskih dobara. Zemlja je zbog svoje plodnosti i sposobnosti da zadovolji čovjekove potrebe prvi Božji dar za održavanje ljudskoga života (AM 31).

Neprijeporno je, kako to upozorava Drugi vatikanski sabor,

da bi stvorena dobra morala pritjecati po pravičnosti svima, pod vodstvom pravde i ljubavi. Ma kakvi bili oblici vlasništva, prilagođeni zakonitim institucijama pojedinih naroda, prema različitim i promjenljivim okolnostima, uvijek treba paziti na tu opću namjenu dobara. Zato čovjek, služeći se tim dobrima, ne smije nikada držati da su stvari koje zakonito posjeduje jedino njegove nego ih također treba smatrati i kao zajedničke, u tom smislu što one mogu koristiti ne samo njemu jedinome nego također i drugima (GS 69).

Socijalni nauk Crkve jasno prepoznaje, ali se to često u stvarnosti zanemaruje, a i premalo o njemu govori, da »u skladu s čovjekovom društvenom naravi, dobro svakoga nužno je u vezi s općim dobrom « (KKC 1905). Uočio je to i Drugi vatikanski sabor: »Kako se međuovisnost ljudi svakim danom povećava i proširuje na čitav svijet, opće dobro, - to jest skup onih uvjeta društvenog života koji grupama i pojedincima omogućuje da potpunije i lakše dođu do vlastitog savršenstva (GS 26).

Da bi se izbjegle mnoge opasne pojave u svijetu, a vidljivo je da su neke već prisutne ( ratovi $^{3}$ i terorizam), »nužna je i svjetska preraspodjela energetskih izvora kako bi im se i one zemlje koje su ih lišene, mogle približiti« (CV 49).

3 Irak, Sirija, Nigerija, Južni Sudan, Ukrajina i područje Južnog kineskog mora neka su zapaljiva mjesta gdje su već izbili sukobi ili su mogući. Na prvi pogled može se činiti da se ti potresi pojavljuju kao neovisni događaji uvjetovani jedinstvenim vlastitim i osebujnim okolnostima. No, malo pomnija raščlamba pokazuje da je, iako se na prvi pogled čini da se sukobi temelje na nekoliko ključnih značajki poput etničkih, religijskih i nacionalnih antagonizma, u srcu većine sukoba zapravo energetski rat. Mnogi sukobi jesu u velikoj mjeri prouzročeni erupcijom dugogodišnjih povijesnih antagonizama među susjednim (često nacionalno izmiješanim) plemenima, sektama i narodima. U Iraku i Siriji, to je sukob između sunita, šijta, Kurda, Turkmena i drugih, u Nigeriji između muslimana, kršćana i različitih plemenskih skupina, u Južnom Sudanu između Dinka i Nuera, u Ukrajini između ukrajinskih lojalista i ruskih separatista povezanih s Moskvom, na Istočnom i Južnom kineskom moru između Kine, Japana, Vijetnama, Filipina i ostalih. Bilo bi pogrješno pripisati sve sukobe samo starim mržnjama, kao što to sugeriraju mnogi analitičari. Neprijateljstva daju sukobima poticaje, ali su ona također potaknuta i najaktualnijim poticajem: željom za nadzorom nad vrijednim izvorima nafte i prirodnog plina. To su, u konačnici, ipak ratovi za osiguravanje energetskih resursa u 21. stoljeću. Nesumnjivo je da je rat u Iraku bio izazvan 
A pritom o sudbini energetskih izvora "ne smije odlučivati ni pravo prvoga ni pravo jačega« (CV 49). Usto, što si siromašne zemlje ne mogu priuštiti pristup neobnovljivim izvorima energije, isključene su iz istraživanja glede tzv. obnovljivih izvora energije, koji pomalo zamjenjuju neobnovljive izvore. A posebice je potrebno izgrađivati održivi razvitak (Cerovac, 1994) temeljen na obnovljivim energijama: »Napredak na području obnovljivih izvora energije iznimno je važan zbog iskorjenjivanja siromaštva. Primjenom i raspodjelom novih i obnovljivih izvora energije moguće je postići mnoge koristi glede zacrtanih ciljeva « (Energy, Justice and Peace, 2014, 128), izjavio je predstavnik Svete Stolice na zasjedanju Generalne skupštine Ujedinjenih naroda.

Neprijeporno je da je još uvijek prisutno iskorištavanje zemalja tzv. Trećeg svijeta, koje se opravdava objašnjenjem da njihovi stanovnici još nisu usvojili načela moderne države. No, »neodgodiva je zadaća međunarodne zajednice iznaći institucionalne putove za reguliranje iskorištavanja neobnovljivih izvora, također uz sudjelovanje siromašnih zemalja i na način zajedničkog planiranja budućnosti« (Energy, Justice and Peace, 2014, 128).

U svjetlu energetskih izazova, koji uključuju cijeli svijet, te s ciljem promicanja globalnog zajedničkog dobra, ljudska bi obitelj trebala usvojiti odgovarajuće mjere. To, kako kaže papa Benedikt XVI., »obvezuje sve međunarodne vođe da rade složno i pokažu spremnost za djelovanje u dobroj vjeri«, te da uspostave »svjetski politički autoritet«, koji će se držati, među ostalim, »načela subsidijarnosti i solidarnosti«, te biti »usmjeren ostvarivanju zajedničkog dobra« (CV 50). On upozorava da je »neusklađenost stvarne međuovisnosti ljudi i naroda s etičkom interakcijom savjesti i umova [...] jedna od velikih opasnosti našeg doba « te referirajući se posebno na pitanje energetike upozorava da »smo na tom polju suočeni s hitnom moralnom potrebom za obnovljivom solidarnošću « (CV 50). A ta potrebna solidarnost, prema riječima pape Ivana Pavla II., »nije, dakle, osjećaj neke neodređene sućuti ili površnog ganuća zbog patnji tolikih ljudi, bliskih ili udaljenih. Naprotiv, to je čvrsta i postojana odlučnost zauzeti se za opće dobro, to jest za dobro svih i svakoga, jer svi smo mi uistinu za sve odgovorni« (SRS 38).

»Budućnost čovječanstva ovisi isključivo o osiguranju opstanka globalnih javnih dobara i o učinkovitoj borbi protiv globalnih javnih zala«, upozorava kardinal Reinhard Marx u knjizi Kapital: Pledoaje za radnika (Marx, 2008, 239). Nema alternative globalizaciji pravednosti i globalizaciji solidarnosti. Predanost izgradnji energetske budućnosti nije samo tehničko pitanje, niti je to jednostavno stvar dogovora politike. Ona također zahtijeva, na mnogo načina, svojevrsno duhovno prepoznavanje nužnosti vjerskog odgovora i etičke preobrazbe. Potrebno je žurno obraćenje srca i uma glede novih vrijednosti: »Ljubav, često zatvorena na područje odnosa bliskosti, ili ograničena na samo subjektivne aspekte djelovanja za drugoga, mora se ponovno promisliti u njezinoj istinskoj valjanosti vrhovnog i općeg kriterija cjelokupne socijalne etike« (Kompendij 369 i 375).

zbog stjecanja nadzora nad tamošnjim naftnim rezervama, odnosno da je bio bitan dio američke strategije, bez obzira na druga, eventualno prihvatljiva, opravdanja invazije na Irak. 
Nužna promjena energetskog obrasca treba osigurati da svatko bude opskrbljen s dovoljno energije potrebne za dostojan život. ${ }^{4} \mathrm{U}$ pregovorima o energetici, u načinu djelovanja ustanova, u društvenoj odgovornosti kompanija nužno je potrebna »nova solidarnost, posebice u odnosima između država u razvoju i onih koje su visoko industrijalizirane« (Ivan Pavao II., 1990, br. 10), kao i unutar pojedine zemlje. Rastuća svijest o globalnoj energetskoj potrošnji treba biti praćena

učinkovitom promjenom mentaliteta, kao i usvajanje novih životnih stilova u kojima će traženje istinitog, i lijepog, i dobrog, i zajedništvo s drugim ljudima u svrhu zajedničkog rasta biti element koji će vladati izborom potrošnje, štednje i investicija (CV 51).

Živjeti energetsku etiku proizlazi iz sveopćeg poziva Drugog vatikanskog sabora na svetost, koji kaže da su laici »pozvani na savršenost« (LG 32), tako da »traže kraljevstvo Božje baveći se vremenitim stvarima i uređujući ih po Bogu « (LG 31). Oni moraju »prepoznati nutarnju narav, vrijednost i uređenje svega stvorenoga na slavu Božju«, kao i »prilike u svijetu, ako gdje na grijeh potiču « (LG 36). U svijetu ima dovoljno energenata za sve, ali su još uvijek nepravedno raspoređeni. Papa Ivan XXIII. poručuje: »Gospodarsko se blagostanje nekoga naroda ima mjeriti ne toliko po sveukupnoj količini dobara što ih posjeduje nego, radije, po njihovoj pravednoj raspodjeli, tako da se svi u državi mogu razvijati i usavršavati« (MM 74).

Energetska problematika može se povezati i s pitanjem ekumenizma, koji Katolička crkva iskreno doživljava s povećanim intenzitetom, jer za nju ekumenski dijalog »nije namijenjen samo ostvarivanju približavanja vjera, nego također $\mathrm{i}$ stvaranju doprinosa za provedbu dobre prakse (Energy, Justice and Peace, 2014, 16). To se često zaboravlja! Još se na Drugom vatikanskom saboru govorilo o »svjetskom općem dobru « (GS 26) kao cilju međunarodne suradnje. Zbog sve veće uzajamne ovisnosti briga za »opće dobro [...] sve više postaje općenita, te zbog toga obuhvaća pravo i dužnosti koje se odnose na čitavo čovječanstvo. Zato svaka skupina mora voditi brigu o potrebnim i zakonitim težnjama drugih skupina, dapače općem dobru ljudske obitelji«(GS 26)..

\section{Zaključak}

Čovječanstvo je danas pozvano da u ovom svijetu živi s izraženom trijeznošću i poštenjem, na što ga, podstiču, među ostalim, i evanđelja: ono »mora uspostaviti takav politički, socijalni i ekonomski poredak da sve bolje služi čovjeku i pomogne pojedincima i skupinama da afirmiraju i razvijaju sebi svojstveno dostojanstvo« (GS 9). Nužno je ostvarivanje „energetske pravde“, a to podrazumijeva poštenu raspodjelu energenata i energetskih usluga, kao i energetskog opterećenja i eksternalija (pristup mreži i sl.), uključivanje i zastupanje zajednice

4 Veliku uzajamnost između energije i siromaštva oslikava disparitet u potrošnji električne energije, primjerice između Švedske, u kojoj prosječno kućanstvo troši 15.000 kWh godišnje, i Tanzanije, s godišnjom potrošnjom od samo 100 kWh (Rubbia, 2006). 
u odlučivanju o energetskoj problematici (primjerice zaštita okoliša i izbor energenta za transformaciju), nepristrani pristup energetskim informacijama i pravnim lijekovima u slučajevima kršenja zakona te osiguravanje da se proizvodnjom i uporabom energije ne krši ljudsko dostojanstvo neovisno o njihovu staležu, statusu ili etničkoj pripadnosti (autorova definicija!). »Iznad određene točke, više energije znači manje pravičnosti«, poručuje Ivan Illich (Sovacool, 2013, 1).

Želi li čovječanstvo ostvariti stabilan mir, a mir uključuje i razna dobra, potrebno je, među ostalim, da se pitanje energije počne shvaćati na pravi način, te da se njezinoj proizvodnji, distribuciji i uporabi pristupi prema novom obrascu. ${ }^{5}$

Ponajprije je, a to posebice danas dolazi do izražaja kod razmatranja svjetske energetske problematike, »nužna učinkovita promjena mentaliteta, kao i usvajanje novih životnih stilova u kojima će traženje istinitog, i lijepog, i dobrog i zajedništvo s drugim ljudima u svrhu zajedničkog rasta biti elementi koji će vladati izborom potrošnje, štednje i investicija « (CA 36), poručuje sveti Ivan Pavao II. Ono treba biti svjesno činjenice da energetska nepravda, konkurencija prirodnim resursima i klimatske promjene mogu uzrokovati mnogim narodima i ljudima velike patnje. Uvažavanje nužnosti pristupa energetskim izvorima je način učinkovitijeg prepoznavanja ljudskog dostojanstva, kao značajke koju je Bog Stvoritelj dao svakoj osobi. Energija potrebna za pristojan život ne može biti nikomu uskraćena činom terorizma ili rata, zbog siromaštva, političke volje ili ekonomskih interesa. Gospodarsko »blagostanje nekoga naroda ima se mjeriti ne toliko po sveukupnoj količini dobara što ih posjeduje nego, radije, po njihovoj pravednoj raspodjeli, tako da se svi u državi mogu razvijati i usavršavati« (MM 74), naglašava papa Ivan XXIII.

Neprijeporno je da je »nužna svjetska preraspodjela energetskih izvora kako bi im se i one zemlje koje su ih lišene, mogle približiti« (CV 49).

Samo zajedničkim posvećenjem raspodjeli moguće je odgovoriti na veliki izazov našeg doba: izgraditi svijet mira i pravde gdje svaka osoba može živjeti dostojanstveno. To se može postići ako prevlada svjetski model istinske solidarnosti, koji stanovnicima planeta osigurava hranu, vodu, potrebnu medicinsku skrb, kao i rad i energetske resurse (!), kao i kulturne prednosti, znanstveno i tehnološko znanje,

poručio je papa Benedikt XVI. (2007). Stoga čovječanstvo mora shvatiti i usvojiti, da je

obveza pravde i ljubavi poduzimanje odlučnih i ustrajnih napora za štedljivo gospodarenje energetskim izvorima, te poštivanje prirode, tako da od toga nema koristi samo čovječanstvo u cjelini, nego i generacije koje tek dolaze (Energy, Justice and Peace, 2014, 33)

5 Zanimljivo je da je Sveta Stolica sudjelovala na izložbi EXPO 2017 (10. lipnja - 10. rujna 2017.) u Astani (Kazahstan) s temom Energija za opće dobro: Briga za zajednički dom. Vidljivo je da je za nastupnu temu izložbe iskorišten podnaslov enciklike Laudato si'. »Tema izložbe EXPO 2017 navodi nas na razmišljanje o načinima postizavanja socijalne pravde na polju energije, te kako omogućiti njezin pristup zemljama koje nemaju energije i resurse, osiguravajući da se energija koristi na čist i etički način«, rekao je kardinal Peter Turkson, voditelj Dikasterija za promicanje cjelovitog ljudskog razvoja (O'Kane, 2017). 
U svemu tome čovječanstvo treba odgovoriti na pitanje pape Franje: »Kakav svijet želimo ostaviti onima koji dolaze poslije nas, djeci koja sada odrastaju? (LS 160).

Kao konačni zaključak mogu poslužiti riječi pape Ivana Pavla II.:

Zacijelo, u tom pravcu nas vodi i Drugi vatikanski sabor kada, opetovano govoreći o potrebi da svijet učinimo čovječnijim, označuje poslanje Crkve u suvremenom svijetu kao ostvarenje te zadaće. Svijet ljudi može postajati uvijek sve čovječnijim jedino ako u mnogostruko područje međuljudskih i društvenih odnosa zajedno s pravednošću unesemo onu milosrdnu ljubav koja tvori mesijansku poruku Evanđelja (DM 14).

\section{Literatura:}

Anon. (s. a.). Energija. U: Hrvatski leksikon. URL: https://www.hrleksikon.info/definicija/ energija.html (04.12.2017.)

Aristotel (2001). Metafizika. Preveo Tomislav Ladan. Zagreb: Signum — Medicinska naklada.

AM. Africae munus. U: Benedikt XVI., Post-synodal Apostolic Exhortation Africae munus. URL: http://w2.vatican.va/content/benedict-xvi/en/apost_exhortations/documents/ hf_ben-xvi_exh_20111119_africae-munus.html (16.12.2017̄.)

Bajsić, Vjekoslav (1991). Spiritual Aspects of Strategic Energy Challenges. Bogoslovska smotra, 61 (1-2), 82-87.

Benedikt XVI. (2007). Angelus: St. Peter's Square: Sunday, 11 November 2007. URL: https://w2.vatican.va/content/benedict-xvi/en/angelus/2007/documents/hf_ben-xvi_ ang_20071111.html (16.09.2017)

CA. Centesimus Annus. U: Ivan Pavao II., Centesimus Annus: Stota godina. Zagreb: Kršćanska sadašnjost, 2001.

Cerovac, Krešimir (1994). Održivi razvoj: jedini izlaz za čovječanstvo. Obnovljeni život, 49 (2), 227-237.

CV. Caritas in veritate. U: Benedikt XVI., Caritas in veritate: Ljubav u istini. Zagreb: Kršćanska sadašnjost, 2009.

DM. Dives in misericordia. U: Ivan Pavao II., Dives in misericordia: Bogat milosrdem. Zagreb: Kršćanska sadašnjost, 1994.

Energy, Justice and Peace (2014). U: Pontifical Council for Justice and Peace, Energy, Justice and Peace: A Reflection on Energy in the Context of Development and Environmental Protection. Vatikan.

GS. Gaudium et spes. U: Josip Turčinović (prir.), Dokumenti: latinski i hrvatski: II. vatikanski koncil (str. 620-768). Zagreb: Kršćanska sadašnjost, 1993.

Ivan Pavao II. (1990). Peace with God the Creator, Peace with All of Creation. URL: http://w2.vatican.va/content/john-paul-ii/en/messages/peace/documents/hf_jp-ii_ mes_19891208_xxiii-world-day-for-peace.html (06.09.2017.)

KKC. Katekizam katoličke crkve. U: Ivan Pavao II., Katekizam katoličke crkve. Zagreb: Hrvatska biskupska konferencija, 2016.

LG. Lumen gentium. U: Josip Turčinović (prir.), Dokumenti: latinski i hrvatski: II. vatikanski koncil (str. 92-204). Zagreb: Kršćanska sadašnjost, 1993.

LS. Laudato si'. U: Franjo, Laudato si': Enciklika o brizi za zajednički dom. Zagreb: Kršćanska sadašnjost, 2015.

Marx, Reinhard (2013). Kapital: Pledoaje za čovjeka. Zagreb: Naklada Zadro.

MM. Mater et magistra. U: Ivan XXIII., Mater et magistra. Zagreb: Kršćanska sadašnjost, 1985. 
Kompendij. U: Papinsko vijeće "Iustitia et Pax", Kompendij socijalnog nauka Crkve. Zagreb: Kršćanska sadašnjost, 2005.

O'Kane, Lydia (2017). Pope sends message to Astana Expo exhibit. U: Vatican Radio. URL: http://en.radiovaticana.va/news/2017/09/02/pope_sends_message_to_astana_ expo_exhibit/1334227 (05.12.2017.)

QA. Quadragesimo anno. U: Papa Pio XI., Enciklika Quadragesimo anno (15. 5. 1931.). Centar za promicanje socijalnog nauka Crkve. URL: http://snc.hbk.hr/public_html/ pio_xi_quadregesimo_anno.pdf (16.06.2016.)

RH. Redemptor hominis. U: Ivan Pavao II., Redemptor hominis: Otkupitelj čovjeka. Zagreb: Kršćanska sadašnjost, 1996.

Rubbia, Carlo (2006). Today the World of Tomorrow — The Energy Challenge. Pontificiae Academiae scientiarum Acta, 18, 275-279. URL: http://www.pas.va/content/dam/ accademia/pdf/acta18/acta18-rubbia.pdf (14.12.2017)

Sovacool, Benjamin K. (2013). Energy and Ethics: Justice and the Global Energy Challenge. Basingstoke: Palgrave Macmillan.

SRS. Sollicitudo rei socialis. U: Ivan Pavao II., Sollicitudo rei socialis: Socijalna skrb. Zagreb: Kršćanska sadašnjost, 1988.

Energy, Justice and Peace from the Perspective of the Social Doctrine of the Church

Krešimir Cerovac*

\section{Summary}

The development of human civilization is closely related to the use of energy and of its multiple sources. From the time of the early hominoids on the planet, seven million years ago, to the present homo sapiens sapiens, energy has been a basic factor affecting the survival of the species. Generally speaking and particularly through her Social Doctrine, the Church demonstrates a special interest in issues concerning integral human development. Thus, the energy issue is also deemed a subject to be dealt with by the Church since it is an exceptional challenge for the purposes of justice, security and peace in the world. Popes John Paul II, Benedict XVI and Francis all have concerned themselves with the question of global energy, being aware that this is an extremely important sign of the times which must be understood, read and interpreted in the light of evangelical wisdom. Nevertheless, matters concerning energy and the energy system are today still a neglected global issue, though an immensely important factor affecting integral development and human dignity.

Key words: energy system, energy policy, energy justice, energy, common good, renewable sources of energy, Pontifical Council for Justice and Peace, consumption, ,justice, peace, security of supply, Social Doctrine of the Church

* Krešimir Cerovac, M.Sc., mag. ing. el. techn.. Address: Našička 2, 10000 Zagreb, Croatia. Email: kresimir.cerovac@xnet.hr 